\title{
The production and utilization of intermediary elemental sulfur during the oxidation of reduced sulfur compounds by Thiobacillus ferrooxidans
}

\author{
W. Hazeu, W. H. Batenburg-van der Vegte, P. Bos, R. K. van der Pas, and J. G. Kuenen \\ Laboratory of Microbiology, Delft University of Technology. Julianalaan 67. VL,-2628 BC Delft, The Netherlands
}

\begin{abstract}
The intermediary production of elemental sulfur during the microbial oxidation of reduced sulfur compounds has frequently been reported. Thiobacillus ferrooxidans, an acidophilic chemolithoautotroph, was found to produce an insoluble sulfur compound, primarily elemental sulfur. during the oxidation of thiosulfate, trithionate. tetrathionate and sulfide. This was confirmed by light and electron microscopy. Sulfur was produced from sulfide by an oxidative step, while the production from tetrathionate was initiated by a hydrolytic step, probably followed by a series of chemical reactions. The oxidation of intermediary sulfur was severely inhibited by sulfhydryl-binding reagents such as $\mathrm{N}$-ethylmaleimide, by the addition of uncouplers or after freezing and thawing of the cells, which probably damaged the cell membrane. The mechanisms behind these inhibitions have not yet been clarified. Finally, it was observed that elemental sulfur oxidation by whole cells depended on the medium composition. The absence of sulfate or selenate reduced the sulfur oxidation rate.
\end{abstract}

Key words: Thiobacillus ferrooxidans - Sulfur production - Sulfur oxidation - Inhibitors - Uncouplers Electron microscopy

Both in the field and in laboratory experiments, the production of some form of elemental sulfur is frequently observed during the oxidation of reduced sulfur compounds by sulfur-oxidizing bacteria. From reviews by Kelly (1982, 1985) and Trüper (1978) it can be concluded that different biochemical mechanisms may be responsible for the oxidation process resulting in different "types" of sulfur. Whether this sulfur is located inside or outside the cells depends on the organisms, the conditions and the sulfur compounds used as substrate. The situation can be even more complex because sulfur production may result from a combination of biological and chemical reactions. However, the exact chemical composition of these sulfur-containing globules has never been specified.

Formation of sulfur not only occurs in neutrophilic. but also in acidophilic sulfur-oxidizing bacteria such as Thiobacillus ferrooxidans, which is considered to be one of the major pyrite-degrading bacteria in (coal) mines and in

Offprint requests to: W. Hazeu

Non-standard abbreviations: NEM, N-ethylmaleimide; CCCP. carbonyl cyanide $\mathrm{m}$-chlorophenyl hydrazone leaching operations. For example, Sato et al. (1976) reported the production of elemental sulfur as an intermediate during the oxidation of reduced sulfur compounds by $T$. forrooridum. The mechanism and the nature of the sulfur formed was not specified. Beyer et al. (1986) studied the microbial leaching of coal with a culture consisting of $T$. ferroovidums and acidophilic heterotrophs. They found that at part of the pyritic sulfur remained on the coal as elemental sulfur. A microbial leaching system for chalcopyrite was developed by Bruynesteyn et al. (1983). The addition of catalytic amounts of silver, in combination with copper sulfate and thiosulfate, resulted in the production of elemental sulfur fiom the sulfide portion of the mineral. With a chalcopyritc-pyrite mixture, the latter mineral was not oxidized. These observations indicate that insight into the production and oxidation of intermediary sulfur by $T$. ferrooxiduns is not only of academic interest, but also of practical importance.

The mechanism of sulfur production from tetrathionate by $T$. ferrocidans has already been investigatged into more detail (Steudel et al. 1987). Analysis of sulfur produced during oxidation of higher concentrations of tetrathionate and pentathionate in aerated suspensions revealed the presence of higher polythionates containing up to 17 sulfur atoms. The main product was sulfur as $S_{8}$, with minor amounts of $S_{6}, S_{7}, S_{9}$ and $S_{12}$. From this research a working hypothesis for the conversion of tetrathionate and higher polythionates to sulfur was postulated. The first step was proposed to be enzymatic hydrolysis of tetrathionate to a sulfane-sulfonic acid and sulfate according to the following equation:

$\mathrm{S}_{4} \mathrm{O}_{6}^{2-}+\mathrm{H}_{2} \mathrm{O} \rightarrow \mathrm{HS}_{2} \mathrm{SO}_{3}^{-}+\mathrm{HSO}_{4}^{-}$.

Under acidic conditions, the presence of sulfane-sulfonic acid ultimately results in the chemical production of sulfite and sulfur by a series of chemical reactions:

$$
\begin{aligned}
& 2 \mathrm{HS}_{2} \mathrm{SO}_{3}^{-} \rightleftharpoons \mathrm{HS}_{4} \mathrm{SO}_{3}^{-}+\mathrm{HSO}_{3}^{-} \\
& 2 \mathrm{HS}_{4} \mathrm{SO}_{3}^{-} \rightleftharpoons \mathrm{HS}_{8} \mathrm{SO}_{3}^{-}+\mathrm{HSO}_{3}^{-} \\
& \mathrm{HS}_{8} \mathrm{SO}_{3}^{-} \rightleftharpoons \mathrm{S}_{8}+\mathrm{HSO}_{3}^{-} .
\end{aligned}
$$

In order to gain more insight into the role of elemental sulfur in the metabolism of $T$. ferrooxidans, the effect of different chemical and physical factors, such as inhibitors and environmental conditions, on sulfur production were investigated. In addition the cytochemical localization of sulfur in the cell was studied by electron microscopy. 


\section{Materials and methods}

In this study a single cell isolate of 7 hiobacillas frrowidam ATCC 19859 (LMD) 81.68) was used. The organism was cultivated in a thiosulfate- or tetrathionate-limited chemostat. More details on the cultivation method. medium composition and the analytical procedures for determination of thiosulfate, tetrathionate, sulfite and sulfide have alreaty been published (Hazeu et al. 1986). Iron-grown cells were cultivated in batch culture in a medium with $180 \mathrm{~m} . \mathrm{M}$ $\mathrm{FeSO}_{4} \cdot 7 \mathrm{H}_{2} \mathrm{O}$ at pH 1.6. according to the method described by Mackintosh (1978).

The respiration rate of cell suspensions after the addition of substrates or inhibitors were measured with a biological oxygen monitor (Yellow Springs Instruments. Yellow: Springs, OH, USA).

The production and oxidation of elemental sulfur from different substrates was investigated by recording the extinction at $430 \mathrm{~nm}$ in the spectrophotometer. with a similar suspension of cells without substrate in the reference cuvette. Elemental sulfur was analysed by centrifuging $2 \mathrm{ml}$ suspension at $20000 \times g$ for 2 min. washing of the pellet with water. recentrifuging and extraction of the pellet overnight with $1 \mathrm{ml}$ acetone. The acetone was separated by centrifuging and decanted. Cyanolysis was carried out in the extraction liciuid by the addition of $1 \mathrm{ml}$ acetone and $0.2 \mathrm{ml} \mathrm{KCN}$ solution. The amount of thiocyanate produced was then determined after the addition of $0.2 \mathrm{ml}$ ferric nitrate solution. analogous with the procedure of Sörbo (1957). The presence of sulfur in the cell was demonstrated by staining of a washed suspension with $2 \% \mathrm{AgNO}_{3}$ in water according to the method of Gromova et al. (1983). The cells were dehydrated, embedded and sectioned by standard procedures. Post-staining of thin sections was limited to uranyl acetate, because the application of lead citrate tended to obscure the rather minute sulfur particles present.

To study the effect of membrane damage on sulfur oxidation, suspensions were frozen in a deep freeze without the addition of protective agents, and thawed at room temperature.

\section{Results}

\section{Observation of elemental sulfur production}

During the oxidation of thiosulfate, trithionate, tetra. thionate and sulfide in concentrations above $10-30 \mu \mathrm{M}$. Thiobacillus ferrooxidans was found to produce some form of elemental sulfur, as observed from the increase of the extinction at $430 \mathrm{~nm}$ in the spectrophotometer. The particle size of the sulfur was generally too small for observation in the light microscope. In Fig. $1 \mathrm{a}$ and $\mathrm{c}$, the change in extinction at $430 \mathrm{~nm}$ during the oxidation of sulfide and tetrathionate by cell suspensions is presented. The shape of the curve resulting from sulfide oxidation generally showed a sharp peak. However, during tetrathionate oxidation. the transition from net sulfur production to net sulfur consumption proceeded more smoothly, giving a more rounded curve. From this type of experiment the intermediary production and consumption of sulfur could easily be followed.

Only when higher substrate concentrations (above $400 \mu \mathrm{M}$ ) were oxidized, elemental sulfur became visible under the light microscope as small refractile globules, frequently attached to the polar end of the cell (Fig. 2). Smaller

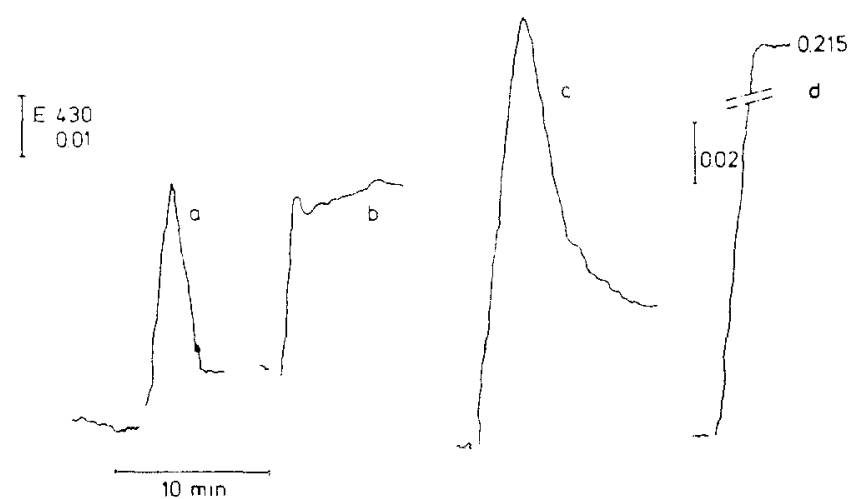

lig. Ia-d. Dillerence in extenction a 430 nm ohservel during sub.

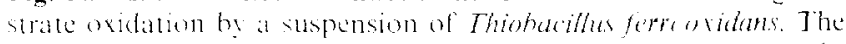
reference cuscte combaned the sane cell suspension without subirate. (Redrawn from recorder lracings). a oxidating of $57 \mu \mathrm{M}$ sulfide: b exidation of 5 ? $\mu \mathrm{M}$ sulfide in the presenee of $1 \mathrm{mM}$ N $\mathrm{N}$ : e oxidation of $70 \mu \mathrm{M}$ terathionate: d oxidation of $70 \mu \mathrm{M}$ carathonate in the presence of $1 \mathrm{mV}$ NFM: note the different scalles

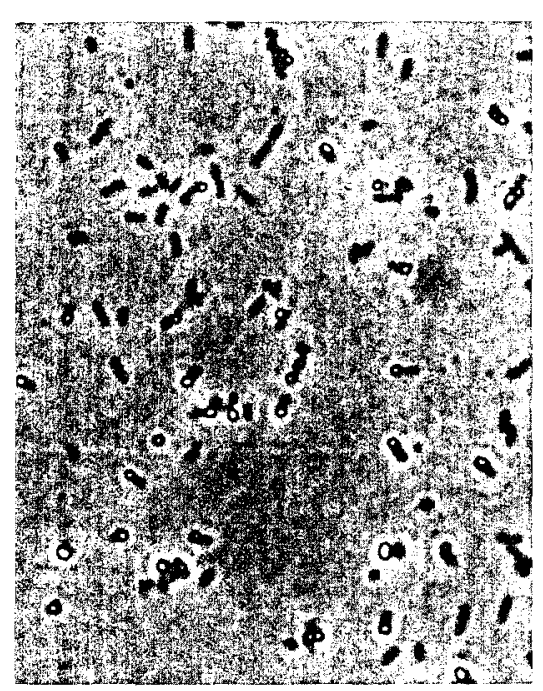

Fig. 2. Cils of T. forrundans producing extracellubir suifur glob. ules during the oxidation of higher tatrathionate enncemations Vold the polar allachment of the sulfur to the cell. Phase contrast 1250

amounts of sulfur could be shown by cytochemical staining with silver nitrate. followed by electron microscopy. As can the seen from Fig. 3b the sulfur was present in the cell wall as tiny globules with a diameter of about $5 \mathrm{~nm}$. it was occasionally also associated with discrete, vacuole-like structures within the cytoplasm (insert Fig. 3 h). Sulfur produced from tetrathionate and from sulfide appeared similar. although differences in the chemical composition may exist.

There was a close correlation between the amount of substrate oxidized, the increase in turbidity of the suspension. the electron microscopical appearance of the cells and the concentration of sulfur extracted from the vell pellets at different intervals.

In subseguent experiments the effect of at number of physical and biochemical factors upon the production and oxidation of sulfur was studied. 


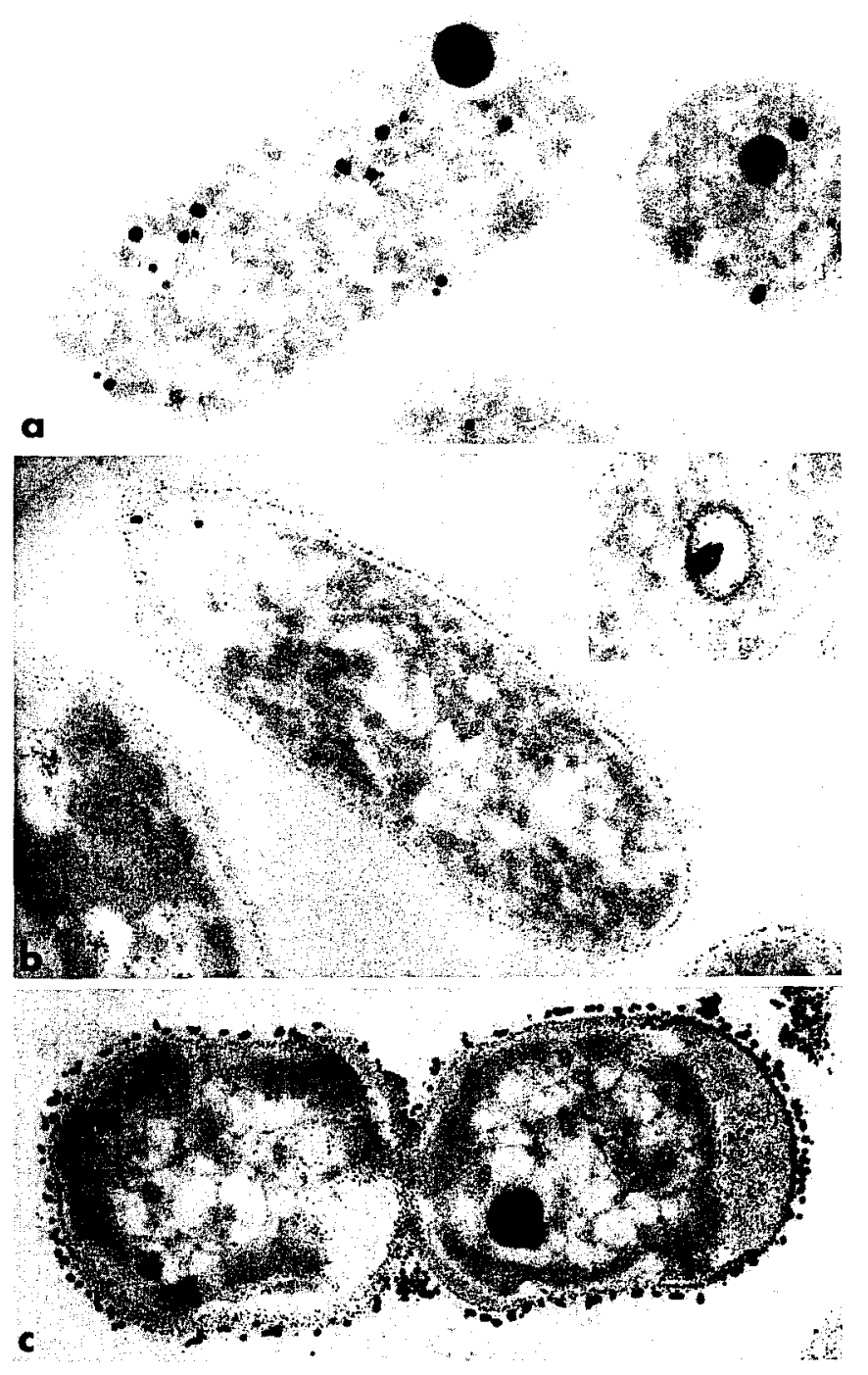

Fig. 3a-c. Electron micrographs of thin sections of $T$. ferrooxidans, stained with $\mathrm{AgNO}_{3}$. a Cells before or after tetrathionate oxidation; b cells during tetrathionate oxidation. The inset shows a vacuolelike structure; $\mathbf{c}$ frozen cells during or after tetrathionate oxidation, $\times 74000$

\section{Influence of NEM}

When the oxygen uptake of suspensions of $T$. ferrooxidans was followed with an oxygen electrode, it was found that the oxidation of thiosulfate, tetrathionate and sulfide was partly inhibited by NEM (Table 1). The total oxygen consumption indicated incomplete oxidation in the presence of NEM. Observation of the change in extinction at $430 \mathrm{~nm}$ during substrate oxidation in the presence of NEM confirmed that the oxidation of elemental sulfur was inhibited (Fig. $1 \mathrm{~b}$ and $1 \mathrm{~d}$ ). Analysis of tetrathionate during its microbial degradation revealed that the first step was not affected by NEM (Results not given).

\section{Effect of uncouplers}

Addition of uncouplers [carbonyl cyanide m-chlorophenylhydrazone (CCCP) or 2,4-dinitrophenol] provoked comparable effects, but only data with CCCP are presented.
Table 1. Initual oxygen consumption rate ( $\mu$ mol mg cels $\cdot$ mint and wat oxygen consumed (pmoli) during oxidation of different substrates by cell suspensions of Thiohacilles ferroxidans in the pres. ence and absence of $3 \mathrm{~m} M \mathrm{NEM}$ (N-ethylmalcimide). The cells had beon grown at $D=0.03 h^{\prime}{ }^{1}$ under tetrathionate limitation

\begin{tabular}{|c|c|c|c|c|}
\hline $\begin{array}{l}\text { Substrate } \\
\text { tested }\end{array}$ & $\begin{array}{l}\text { Conc } \\
(\mu \mathrm{M})\end{array}$ & $\begin{array}{l}\text { NEM } \\
\text { added }\end{array}$ & $\begin{array}{l}\text { Oxygen } \\
\text { consumption } \\
\text { rate ( } 4 \text { mol } \\
\text { mg min) }\end{array}$ & $\begin{array}{l}\text { Oxygen } \\
\text { consumed } \\
(\mu \text { mot } 1)\end{array}$ \\
\hline $\mathrm{Na}_{2} \mathrm{~S}$ & 100 & - & $\begin{array}{l}0.20 \\
0.13\end{array}$ & $\begin{array}{r}125 \\
38\end{array}$ \\
\hline $\mathrm{Va}_{2} \mathrm{~S}_{4} \mathrm{O}_{6}$ & 50 & + & $\begin{array}{l}027 \\
0.07\end{array}$ & $\begin{array}{r}142 \\
24\end{array}$ \\
\hline $\mathrm{Na}_{2} \mathrm{~S}_{2} \mathrm{O}_{3}$ & 100 & + & $\begin{array}{l}0.32 \\
0.33\end{array}$ & $\begin{array}{r}178 \\
46\end{array}$ \\
\hline
\end{tabular}

Table 2. Initial oxygen consumption rate during oxidation of different substrates by Thiobacillus ferrooxidans in the absence and pres. ence of $37 \mu \mathrm{M}$ (CC.P (carbonyl cyanide m-chlorophenyl hydrazone)

\begin{tabular}{|c|c|c|c|c|c|}
\hline \multirow[t]{2}{*}{$\begin{array}{l}\text { Substrate } \\
\text { tested }\end{array}$} & \multirow[t]{2}{*}{$\begin{array}{l}\text { Conc } \\
(\mu \mathrm{M})\end{array}$} & \multicolumn{2}{|c|}{$\begin{array}{l}\text { Oxygen consump- } \\
\text { tion rate } \\
\text { (umol/mg } \mathrm{min})\end{array}$} & \multicolumn{2}{|c|}{$\begin{array}{l}\text { Oxygen consumed } \\
\text { (fmolil) }\end{array}$} \\
\hline & & $-\mathrm{CCCP}$ & $+\mathrm{CCCP}$ & $-\mathrm{CCCP}$ & $+C C C P$ \\
\hline $\mathrm{Na}_{2} \mathrm{~S}$ & 100 & 0.23 & 0.06 & 173 & 48 \\
\hline $\mathrm{Na}_{2} \mathrm{~S}_{2} \mathrm{O}_{3}$ & 100 & 0.35 & 0.25 & 180 & 60 \\
\hline $\mathrm{Na}_{2} \mathrm{~S}_{+} \mathrm{O}_{5}$ & 50 & 0.27 & 0.09 & 161 & 36 \\
\hline$S^{\circ}$ (acelone) & - & 0.15 & 0.006 & 36 & 2 \\
\hline $\mathrm{Na}_{2} \mathrm{SO}_{3}$ & 100 & 0.09 & 0.09 & 50 & 46 \\
\hline
\end{tabular}

With thiosulfate, tetrathionate, sulfide, and especially with sulfur, respiration during substrate oxidation was partly inhibited (Table 2). The oxidation of sulfite was either not affected or slightly stimulated. The first step of tetrathionate degradation was not inhibiled by the presence of uncouplers A slight acceleration could even be observed (Fig. 4). The relatively faster increase in turbidity during substrate oxidation indicated that uncouplers specifically inhibited the oxidation of intermediary elemental sulfur.

\section{Effect of freezing and thawing of the cells}

The phenomena produced by freezing and thawing of the suspension (Table 3) were identical to those observed in the presence of uncouplers. As can be noted, the (low) rate of oxidation of sulfite was not affected, but the oxidation of the other substrates was significantly affected. Quantitative analysis showed that the oxidation did not proceed further than to the level of sulfur. Electron microscopy of frozen suspensions producing intermediary sulfur revealed the presence of sulfur deposits larger than observed under normal conditions (Fig. 3c). These globules seemed to be partly cmbedded in the periplasm and outer membrane of the cell, while the smaller particles were primarly found in the middle layer between the cytoplasm and the outer membrane. In addition, it was found that a few cells were lysed, or that the cytoplasm had contracted. 


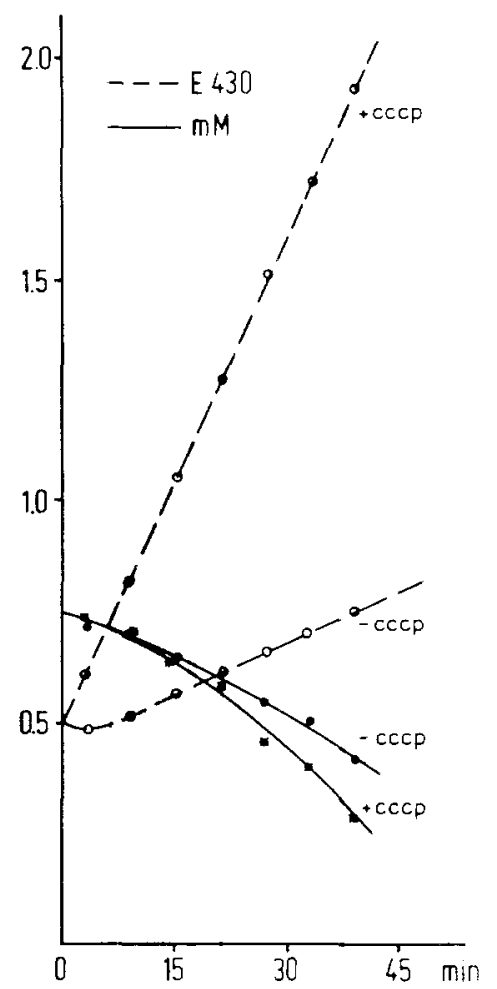

Fig. 4. Oxidation of tetrathionate and increase in extinction at $430 \mathrm{~nm}$ in a continuously aerated cell suspension of tetrathionatcgrown $T$. ferrooxidans in the absence and presence of $37 \mu \mathrm{N} \mathrm{CCCP}$

Table 3. Effect of freezing and thawing on the oxidation of different substrates by Thiobacillus ferrooxidans. Oxygen consumption by fresh cells was lincar for at least $10 \mathrm{~min}$. However, in frozen cells the respiration rate gradually decreased after addition of the substrate. In the latter case, the initial rate is given, indicated by $\downarrow$

\begin{tabular}{llll}
\hline Substrate tested & $\begin{array}{l}\text { Conc } \\
(\mu \mathrm{M})\end{array}$ & $\begin{array}{l}\text { Initial oxygen consumption } \\
\text { rate }\left(\mu \mathrm{mol} m \mathrm{~m}^{-} \mathrm{min}\right)\end{array}$ \\
\hline & & Fresh cells & Frozen cells \\
\hline $\mathrm{Na}_{2} \mathrm{~S}$ & 133 & 0.14 & $0.09 \downarrow$ \\
$\mathrm{Na}_{2} \mathrm{~S}_{2} \mathrm{O}_{3}$ & 133 & 0.25 & $0.26 \downarrow$ \\
$\mathrm{Na}_{2} \mathrm{~S}_{4} \mathrm{O}_{6}$ & 133 & 0.19 & $0.11 \downarrow$ \\
$\mathrm{Na}_{2} \mathrm{SO}_{3}$ & 330 & 0.03 & 0.03 \\
\hline
\end{tabular}

\section{The role of sulfate anions}

Finally, it was observed that the composition of the suspension medium greatly influenced the oxidation rates of some substrates. Washing of the cells and resuspension in water acidified to $\mathrm{pH} 3$ with $\mathrm{HCl}$ reduced the rate of tetrathionate oxidation at concentrations greater than $100 \mu \mathrm{M}$. In addition, at tetrathionate concentrations above $50 \mu \mathrm{M}$ an increasing lag phase was observed during experiments using the oxygen electrode. Addition of sulfate $(25-50 \mathrm{mM}) \mathrm{com}$. pletely abolished the lag phase, and re-established the normal tetrathionate degradation rate (Fig. 5). In contrast, the initial respiration rate during sulfide oxidation, as measured with the oxygen electrode, was increaed in sulfate-free medium. However, after oxidation of the sulfide to sulfur, as

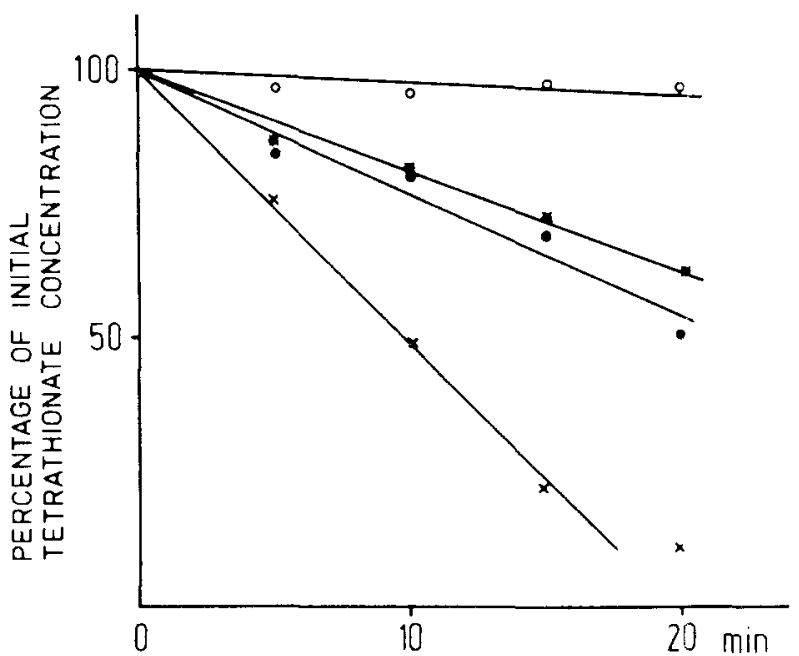

Fig. 5. The oxidation of $400 \mu \mathrm{M}$ tetrathonate by colls of Thobacilles ferroxidans in their growth medium of in demineratized water-HCl pH 3.0. supplemented with different concentrations of $\mathrm{Na}_{2} \mathrm{SO}_{4} \times$ Original suspension: suspension in demineralized water-HCl; * suspension in demineralized water. $\mathrm{HCl}+10 \mathrm{mM}$ $\mathrm{Na}_{2} \mathrm{SO}_{4}:-$ suspension in demineralized water-HCl $-25 \mathrm{mM}$ $\mathrm{Nal}_{2} \mathrm{SO}_{4}$

observed in the spectrophotometer and confirmed by analysis, sulfur oxidation was delayed. Addition of sulfate at the concentration present in the culture medium established the normal sulfur oxidation rate. both with tetrathonate- and iron-grown cells (Fig. 6). Of the anions tested phosphate. arsenate molybdate, tungstate, selenate and selenite), only selenate proved to be effective in replacing sulfate in establishing both the "normal" tetrathonate and sulfur oxidation rates Millimolar concentrations of the other anions had no, or even an inhibitory effect.

\section{Discussion}

In the literature on microbial leaching, pyrite oxidation is often considered as an indirect process, with ferric iron as the primary oxidant. The role of Thiohacillus ferrooxidans should then primarily be the regeneration of ferric iron (Silverman 1967). This is rather unlikely on the basis of biochemical data (Arkesteyn 1980) and in view of the observed yields of $T$. ferrooxidans grown on pyrite, which. indicate that the yield on this combined ferrous sulfur compound is much higher than on the equivalent amount of ferrous iron (Hazeu et al. 1987). Furthermore, pyrite-grown cells possess the ability to oxidize both ferrous iron and sulfur compounds (Arkesteyn 1980; Hazeu et al. 1987). Finally, it was observed that iron-grown cells were able to oxidize sulfide and sulfur (Fig. 6), indicating that the ability to oxidize sulfide is constitutive in $T$. ferrooxidans. This implies that in the study of the role of $T$. ferrooxidans in microbial leaching, sulfur oxidation must also be considered.

Although sulfur production during the oxidation of reduced sulfur compounds by thiobacilli has been observed before (Kelly 1982.1985; Trüper 1978), relatively little attention has been paid to the different factors involved in this phenomenon, and to the chemical composition of the sulfur.

From the investigations of Steudel et al. (1987), a model for the composition of "biological" sulfur was proposed. 


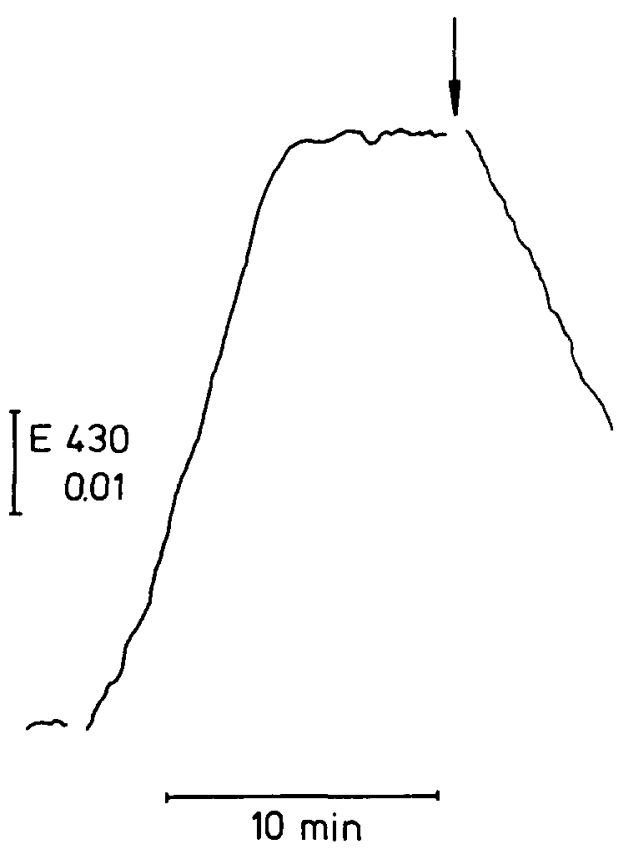

Fig. 6. Effect of $\mathrm{Na}_{2} \mathrm{SO}_{4}$ on the oxidation of sulfur produced from $100 \mu \mathrm{M}$ sulfide by iron-grown, washed cells of $T$. ferrooxidans. suspended in demineralized water $-\mathrm{H}_{2} \mathrm{SO}_{4} \mathrm{pH} 3.0$. The arrow indicates the addition of $30 \mathrm{mM} \mathrm{Na}{ }_{2} \mathrm{SO}_{4}$. Redrawn from recorder tracing

They demonstrated the presence of higher polythionates in combination with different species of sulfur, suggesting that the sulfur globules are in fact solubilized by these polythionates. This combination results in a hydrophilic. and therefore reactive type of sulfur. This differs from the properties of pure elemental sulfur, which is hydrophobic. From the observations using the spectrophotometer (Fig. 1). it can be concluded that during laboratory experiments some form of elemental sulfur can be produced, both from polythionates and from sulfide. Because of the subtle nature of this process, it may have escaped attention, unless relatively high concentrations of sulfur were formed. Our observations are similar to those of Schedel and Trüper (1980) who also observed sulfur production from thiosulfate by another organism: Thiobacillus denitrificans. The sulfur could not be seen under the light microscope, but was apparent from the milky appearance of the cell suspension.

The shape of the curves presented in Fig. 1 depended on the oxidized substrate, and on the growth conditions. It should be realised, however, that the production of sulfur is the result of a dynamic situation in which the sulfur degradation proceeds slowly relative to its production. Under different growth conditions, or with other organisms (results not shown), the production of elemental sulfur could only be demonstrated by inhibiting its further oxidation by, for example, $\mathrm{N}$-ethylmaleimide (NEM).

The distribution of the sulfur in the cells agrees with that reported by Gromova et al. (1983) and by Karavaiko et al. (1984). These investigators were studying the uptake of sulfur by $T$. ferrooxidans. In our study on intermediary sulfur production, this compound was mainly found in the outer membrane of the cell wall and in vacuole-like structures. It was not present in the cytoplasmic membrane, as might be expected if the sulfur produced had a lipophilic character. This also suggests that the sulfur globules are hydrophilic, as stated before. Sulfur found in Beggiama and Chromutium (Strohl et al. 1981; Trüper 1978) was reported to be present in special structures surrounded by a membrane. In $T$. ferrooxidans, this has never been observed. It is not clear if the vacuoles seen in the cytoplasm may have resulted from invaginations of the cytoplasmic membrane, as found in Beggiatoa. The sulfur globules found in cells which had been frozen and thawed before the test (Fig 3) had unusual dimensions. The phenomenon may indicate some transition phase between the small, periplasmic sulfur globules and the larger globules of over $200 \mathrm{~nm}$ diameter observed outside the cells (Fig. 2). From these spectrophotometric and microscopic obscrvations, there can be no doubt that intermediary elemental sulfur production occurs during the oxidation of a number of reduced sulfur compounds.

The inhibitory effect of NEM on the oxidation of sulfur. but not on the oxidation of other reduced sulfur compounds. strongly suggests that sulfhydryl-containing enzymes may only be involved during elemental sulfur oxidation. Arkesteyn (1980) also reported complete inhibition of sulfur oxidation in $T$. ferrooxidans by $1 \mathrm{mM}$ NEM.

Both uncouplers and freezing and thawing of the cells affected the oxidation of different substrates in a specific way. Although the initial respiration rates with thiosulfate and sulfite might suggest that most cells appeared to be intact after freezing, the inhibition of elemental sulfur oxidation demonstrated otherwise. The inhibition by uncouplers suggests that the condition of the membrane or the membrane potential plays an essential role during elemental sulfur oxidation. This might imply that an active transport step is involved in sulfur oxidation, the activation of the sulfur molecule or the requirement for a reduced cofactor e.g. NAD(P)H produced by reversed electron flow It has been postulated by Suzuki (1965) for Thiobacillus thiooxidans and by Emmel et al. (1986) for Sulfolobus brierleyi that sulfur may be oxidized by an oxygenase, because ${ }^{18} \mathrm{O}$ was incorporated into sulfate or sulfite during their experiments. The type of oxygenase was not specified. It should be noted, however, that the total ${ }^{18} \mathrm{O}$ incorporation was relatively low. For the elucidation of the inhibition of sulfur oxidation, the demonstration and purification of a cell-free, sulfur-oxidizing enzyme system will be required.

Although the sulfate-dependence of tetrathionate and elemental sulfur oxidation might suggest the operation of a common enzyme (Figs. 5 and 6 ), this is unlikely because iron-grown cells which cannot oxidize thiosulfate or tetrathionate also showed sulfate-dependent sulfur oxidation (Hazeu et al. 1987). Lazaroff (1977) reported that for optimal ferrous iron oxidation by $T$. ferrooxidans, the sulfate anion was required. Other anions were found to be inhibitory, but selenate could partly replace sulfate. Fry et al. (1986) demonstrated that during iron oxidation, a sulfatedependent electron paramagnetic resonance signal could be observed. They suggested that the signal indicated the presence of an iron-sulfur cluster active during ferrous oxidation. From our observations, it can be concluded that the presence of sulfate anions has a broader significance, as also the tetrathionate- and elemental sulfur-oxidizing enzyme systems are affected. Recently Lu and Kelly (1988a) reported that trithionate oxidation by Thiobacillus tepidarius depended on the presence of sulfate in the medium. More research is needed for clarification of the role of sulfate in the oxidation of reduced sulfur compounds. 
The mechanism of tetrathionate degradation. as proposed by Steudel et al. (1987) implies that in sulfur production from this compound a hydrolytic step is primarily involved, while the initial attack on sulfide is oxidative. In cell free extracts of $T$. ferrooxidans, an enzyme for the degradation of tetrathionate has now been demonstrated. supporting this hypothesis (Results to be published separately). A comparable enzyme has also been reported for Thiobacillus ferrooxidans (Okuzumi 1966), indicating that the first step of tetrathionate degradation might be a dismutation, leading to the production of trithionate and pentathionate. This observation, together with the results reported here might suggest that in acidophilic thiobacilli polythionate degradation is initiated by a hydrolytic step. The finding of Lu and Kelly (1988b) of a "trithionate hydrolyase" in the neutrophilic bacterium $T$. tepidarius. means that hydrolytic enzymes might have a broader significance in dissimilative sulfur metabolism.

Acknowledgement. The authors are grateful to Lesley A Robertson for correcting the English text.

\section{References}

Arkesteyn GJMW (1980) Contribution of microorganisms to the oxidation of pyrite. Thesis, Agricultural University. Wageningen, The Netherlands

Beyer M, Ebner HG, Klein J (1986) Influence of pulp density and bioreactor design on microbial desulphurization of coal App Microbiol Biotechnol 24:342-346

Bruynesteyn A, Lawrence RW, Vizsolyi A. Hackl R (1983) An elemental sulphur producing biohydrometallurgical process for treating sulphide concentrates. In: Rossi G. Torma AE (eds) Progress in biohydrometallurgy. Associazione Mineraria Sarda. Iglesias, pp $151-168$

Emmel T, Sand W, Konig WA, Bock E (1986) Evidence for the existence of a sulphur oxygenase in Sulfolobus brierleyi. J Gen Microbiol 132:3415-3420

Fry IV, Lazaroff N, Packer L (1986) Sulfate-dependent iron oxidation by Thiobacillus ferrooxidans: Characterization of a new EPR detectable electron transport component on the reducing side of rusticyanin. Arch Biochem Biophys 246:650 - 654

Gromova LA, Karavaiko GI, Sevtsov AV, Pereverzev NA (1783) Identification and distribution of sulfur in Thiobacillus ferrooxidans cells. Microbiology 52:357-363

Hazeu W, Bijleveld W, Grotenhuis JTC, Kakes E, Kuenen JG (1986) Kinetics and energetics of reduced sulphur oxidation by chemostat cultures of Thiobacillus ferrooxidans. Antonie van Leeuwenhoek J Microbiol 52:507-518

Hazeu W, Schmedding DJ, Goddijn O, Bos P, Kuenen JG (1987) The importance of the sulphur oxidizing capacity of Thiobacillus formoxidams during leaching of pyrite. In. Neijssel on. Meer fan der RR. I uvben $k$ (eds) Proc th European Congress on Biolechnology 1957. sol ? Blsevier. Amsterdam oxford vew York Tokyo. pp $497-494$

Karavaiko Gil, Gromova LA. Pereverzev Ni) (1984) Vature of sulfur-containing components and its functons ir. Thiolacilhes forrowidans cells. Microbiology 52:433-2.37

Kelly DP (1982) Biochenistry of the chemolithotropic oxidation of inorganic sulphur. Phil Trans Roy Soc Lond B 298 . $499-$ 528

Kelly DP (1985) Physiology of the thobacills elueddang the sulphur oxidation pathwaly. Nicrobiol Sci $2: 105-1169$

Lizaroll $N$ (1977) The specificity of the anonic recpurement for iron oxidation by Thiobacillas fermoxidems. I Gen Vicobobol $101: 85-92$

L. WP. Kelly DP (1988: Kinetic and encrgetic aspeces of inorganic sulphur compound oxidation by Thiobacillas tepitarias. I Gen Microbiol 134:865-870

L. WP. Kelly DP ( 1988 b) Cellular location and partal purfication of the "thosulphate-oxiding enyme" and trithonate hydrolyase" from Thiohaillus tipidarits. I Gen Nicrobiol 134 $877-885$

Mackintosh ME (1978, Vitrogen tixation by Thiofactlos femm. axidans. J Gen Microbiol 105:215-218

Okuzumi M(1966) Studies on biochemistry of the Thobacill part 8. Dismulation of terathionate by Thiofucillus thomidums Agr Biol Chem 30:313-318

Sato T. Mizoguchi T, Okabe T (1976) Oxidation of inorgante sulfur compounds by thiobacilli. J Ierment Technol 54.361 -. 368

Schedel M. Trüper HG (1980) Anaerobic oxidation of thiosulfate and elemental sulfur in Thiobacillus dentrificams Arch Micro. biol $124: 205-210$

Silverman MP (1967) Mechansms of baterial pyrits oxidation. I Bacteriol 94:1046-1051

Sörbo B (1957) A colorimetre method for the deturmmation of thiosulfate. Biochim Biophys Acta $23+412 \cdots+16$

Steudel R. Hold G, Göhel T, Haze W (1987) Chromatographic separation of higher polythionates $\mathrm{S}_{n} \mathrm{O}_{t}^{\frac{7}{n}} \quad(n=3.22)$ and their detection in cultures of Thohacillus ferrowidan: Moleculat composition of bacterial sulfur secretions. Angew Chem Int Ed Engl 26:151-153

Strohl WR, Getfers 1. Larkin LM (1981) Structure of the sulfur inclusion envelopes from four Beggiatous. Curt Microbiol $6: 75-79$

Suzuki I (1965) Incorporation of atmospheric oxygen-18 inw thiosulfate by the sulfur-oxidizing enzyme of Thiobacillus thiooxidans. Biochim Biophys Acta 110:97-101

Trüper HG (1978) Sulfur metabolism. In: Clayton RK. Sistrom WR (eds) The photosynthetic bacteria. Plenum Press. New York London, pp $677-690$

Received July 4. 1988 i Accepted July 18. 1988

\section{Note added in proof}

The observations reported in this paper, and the investigations carried out by Steudel et al. (1987), indicate that sulfur produced by bacteria differs significantly from other types of elemental sulfur. We therefore support the suggestion of Steudel (1988) that for bacterial sulfur the term "elemental sulfur" should be replaced by "hydrophilic sulfur" in order to highlight the main difference.

Steudel R (1988) On the nature of the "elemental sulfur" ( $\mathrm{S}^{\circ}$ ) produced by sulfur oxidizing bacteria - a model for $S^{\circ}$ globules. In Schlegel HG, Bowin B (eds) Biology of autotrophic bacteria. chapter 16. Science Tech Publishers, Madison, USA (in press) 